\title{
Role of Oxidative Stress in Transformation Induced by Metal Mixture
}

\author{
Silva-Aguilar Martín, Rojas Emilio, and Valverde Mahara \\ Departamento de Medicina Genómica y Toxicología Ambiental, Instituto de Investigaciones Biomédicas, \\ Universidad Nacional Autónoma de México, Ciudad Universitaria 04510, DF, Mexico \\ Correspondence should be addressed to Valverde Mahara, mahara@biomedicas.unam.mx
}

Received 8 August 2011; Accepted 7 September 2011

Academic Editor: Guillermo Zalba

Copyright (๑) 2011 Silva-Aguilar Martín et al. This is an open access article distributed under the Creative Commons Attribution License, which permits unrestricted use, distribution, and reproduction in any medium, provided the original work is properly cited.

\begin{abstract}
Metals are ubiquitous pollutants present as mixtures. In particular, mixture of arsenic-cadmium-lead is among the leading toxic agents detected in the environment. These metals have carcinogenic and cell-transforming potential. In this study, we used a two step cell transformation model, to determine the role of oxidative stress in transformation induced by a mixture of arseniccadmium-lead. Oxidative damage and antioxidant response were determined. Metal mixture treatment induces the increase of damage markers and the antioxidant response. Loss of cell viability and increased transforming potential were observed during the promotion phase. This finding correlated significantly with generation of reactive oxygen species. Cotreatment with $N$-acetylcysteine induces effect on the transforming capacity; while a diminution was found in initiation, in promotion phase a total block of the transforming capacity was observed. Our results suggest that oxidative stress generated by metal mixture plays an important role only in promotion phase promoting transforming capacity.
\end{abstract}

\section{Introduction}

Arsenic (As), cadmium (Cd), and lead ( $\mathrm{Pb}$ ) are commonly used in numerous industries to the extent that they have now generated a pollution problem. Numerous studies have reported high levels of these metals near smelter areas [1]. Acute exposure to $\mathrm{As}, \mathrm{Cd}$, and $\mathrm{Pb}$ produces a variety of toxic effects in several target organ systems; however, most individuals are chronically exposed to low levels of a mixture of these metals [2, 3]. These three metals/metalloids share several common mechanisms underlying their toxicities, including production of oxidative stress, reaction with sulfhydryl groups, and interference with essential metals. In addition, stress proteins and antioxidant enzymes have been proposed to provide common cellular protective mechanisms against the element-induced toxicities when they occur on an individual basis [4]. Furthermore, these metals have been listed in the top ten hazardous substances and proposed as one of the mixtures for interaction profile studies by the Agency for Toxic Substances and Disease Registry (ATSDR). As and Cd have been classified as carcinogens and $\mathrm{Pb}$ as a possible carcinogen by the International Agency in Research of Cancer (IARC) [5-9].

$\mathrm{As}, \mathrm{Cd}$, and $\mathrm{Pb}$ induce the generation of reactive oxygen species (ROS), which can damage DNA, lipids, and proteins. As generates ROS in the form of superoxide $\left(\mathrm{O}^{\cdot}{ }^{--}\right)$, singlet oxygen $\left({ }_{1} \mathrm{O}^{2}\right)$, peroxyl radical $\left(\mathrm{ROO}^{\bullet}\right)$, nitric oxide $\left(\mathrm{NO}^{\bullet}\right)$, hydrogen peroxide $\left(\mathrm{H}_{2} \mathrm{O}_{2}\right)$, dimethylarsinic peroxyl radicals $\left(\left[\left(\mathrm{CH}_{3}\right)_{2} \mathrm{AsOO}^{\bullet}\right]\right)$, and the dimethylarsinic radical $\left[\left(\mathrm{CH}_{3}\right)_{2} \mathrm{As}{ }^{\bullet}\right][10,11]$. Cd generates ROS in the form of superoxide $\left(\mathrm{O}^{\bullet-}\right)$, hydrogen peroxide $\left(\mathrm{H}_{2} \mathrm{O}_{2}\right)$, hydroxyl radical $\left(\mathrm{HO}^{\bullet}\right)$, and lipid radicals $\left(\mathrm{L}^{\bullet}\right)$. In addition, $\mathrm{Cd}$ treatment can cause the replacement by iron in some enzymes, and the accumulated iron molecules reacts with $\mathrm{H}_{2} \mathrm{O}_{2}$ to produce hydroxyl radicals $\left(\mathrm{HO}^{\bullet}\right)[10,11]$. Pb ROS-generating mechanism is mediated by delta-aminolevulinic acid dehydratase $(\delta$-ALAD) inhibition, which provokes the accumulation of delta-aminolevulinic acid ( $\delta$-ALA). $\delta$-ALA is rapidly oxidized to generate free radicals such as superoxide $\left(\mathrm{O} 2^{\bullet-}\right)$, hydroxyl radicals $\left(\mathrm{HO}^{\bullet}\right)$, and hydrogen peroxide $\left(\mathrm{H}_{2} \mathrm{O}_{2}\right)$ $[10,12]$. 


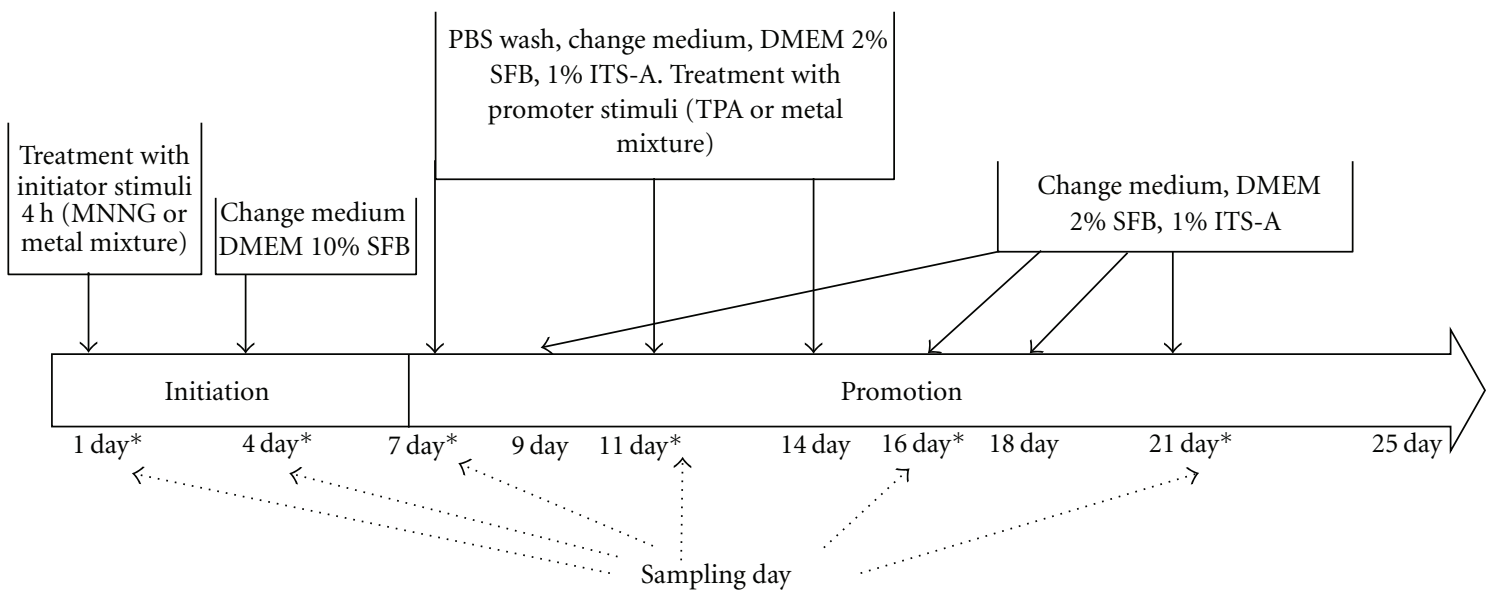

Figure 1: Scheme of two-phase transformation protocol, Balb/c 3T3 cells. Initiation phase, day 1 to 7 . On day 1, subconfluent cell culture was treated with MNNG $0.5 \mu \mathrm{g} / \mathrm{mL}$ (positive initiator) or metal mixture $\left.\left(2 \mu \mathrm{M} \mathrm{NaAsO}_{2}, 2 \mu \mathrm{M} \mathrm{CdCl}_{2} \text {, and } 5 \mu \mathrm{M} \mathrm{Pb}\left(\mathrm{C}_{2} \mathrm{H}_{3} \mathrm{O}_{2}\right)\right)_{2} \cdot 3 \mathrm{H}_{2} \mathrm{O}\right)$ as initiator stimuli during $4 \mathrm{~h}$ and reseeded in DMEM medium supplemented with $10 \%$ SFB. On day 4 medium was changed. Promotion phase begins on day 7 and ends on day 25. In promotion phase, cells were cultured in DMEM medium supplemented with $2 \%$ SFB and $1 \%$ ITS-A. On days 7,11 , and 14 cells were treated with TPA $0.1 \mu \mathrm{g} / \mathrm{mL}$ (positive promoter) or metal mixture $\left(2 \mu \mathrm{M} \mathrm{NaAsO}_{2}, 2 \mu \mathrm{M} \mathrm{CdCl}_{2}\right.$ and $\left.5 \mu \mathrm{M} \mathrm{Pb}\left(\mathrm{C}_{2} \mathrm{H}_{3} \mathrm{O}_{2}\right)_{2} \cdot 3 \mathrm{H}_{2} \mathrm{O}\right)$ as promoter stimuli. Meanwhile, on days 9, 16, 18, and 21 medium changes were done. Sampling days across transformation protocol are represented by “*”; in these days samples were taken before changing media or applying treatment.

TABLE 1: Transforming potential through initiation phase.

\begin{tabular}{|c|c|c|c|c|c|}
\hline \multicolumn{6}{|c|}{ Initiation phase } \\
\hline Day & Treatment $^{\mathrm{a}}$ & Viability $(\%)^{\mathrm{b}}$ & $\begin{array}{l}\text { Dish with foci/dish } \\
\text { scored }^{c}\end{array}$ & $\begin{array}{l}\text { No. of transformed } \\
\text { foci/dish }\end{array}$ & $\mathrm{TP}^{\mathrm{d}}$ \\
\hline \multirow{5}{*}{1} & Control & $100 \pm 5.5$ & $4 / 6$ & $1.8 \pm 0.05$ & $1 \pm 0.27$ \\
\hline & $\mathrm{MNNG}+\mathrm{TPA}$ & $96 \pm 4.8$ & $6 / 6$ & $62.25 \pm 9.9^{* * *}$ & $35.37 \pm 5.6^{* * *}$ \\
\hline & Metal mixture + TPA & $100 \pm 1.7$ & $6 / 6$ & $33.75 \pm 11.6^{* * *}$ & $18.41 \pm 6.3^{* * *}$ \\
\hline & MNNG + metal mixture & $96 \pm 4.8$ & $6 / 6$ & $23 \pm 7.7^{* * *}$ & $2.61 \pm 0.88$ \\
\hline & Metal mixture + metal mixture & $100 \pm 1.7$ & $6 / 6$ & $29.5 \pm 5.7^{* * *}$ & $3.22 \pm 0.62$ \\
\hline \multirow{4}{*}{4} & Control & $100 \pm 0.0$ & $4 / 6$ & $1.8 \pm 0.05$ & $1 \pm 0.27$ \\
\hline & MNNG + TPA & $89 \pm 5.8$ & $6 / 6$ & $62.25 \pm 9.9^{* * *}$ & $22.7 \pm 3.6^{* * *}$ \\
\hline & Metal mixture + TPA & $89 \pm 9.1$ & $6 / 6$ & $33.75 \pm 11.6^{* * *}$ & $12.4 \pm 4.2^{* * *}$ \\
\hline & MNNG + metal mixture & $89 \pm 5.8$ & $6 / 6$ & $23 \pm 7.7^{* * *}$ & $3.2 \pm 1.1$ \\
\hline \multirow{6}{*}{7} & Metal mixture + metal mixture & $89 \pm 9.1$ & $6 / 6$ & $29.5 \pm 5.7^{* * *}$ & $1.9 \pm 0.4$ \\
\hline & Control & $100 \pm 0.25$ & $4 / 6$ & $1.8 \pm 0.05$ & $1 \pm 0.27$ \\
\hline & $\mathrm{MNNG}+\mathrm{TPA}$ & $83 \pm 2.8^{* *}$ & $6 / 6$ & $62.25 \pm 9.9^{* * *}$ & $83.5 \pm 13.4^{* * *}$ \\
\hline & Metal mixture + TPA & $93 \pm 0.12^{* *}$ & $6 / 6$ & $33.75 \pm 11.6^{* * *}$ & $66.5 \pm 22.8^{* * *}$ \\
\hline & MNNG + metal mixture & $83 \pm 2.8^{* *}$ & $6 / 6$ & $23 \pm 7.7^{* * *}$ & $6.2 \pm 2.1^{*}$ \\
\hline & Metal mixture + metal mixture & $93 \pm 0.12^{* *}$ & $6 / 6$ & $29.5 \pm 5.7^{* * *}$ & $9.4 \pm 1.8^{*}$ \\
\hline
\end{tabular}

${ }^{\mathrm{a}}$ Treatments were added at concentrations of MNNG $0.5 \mu \mathrm{g} / \mathrm{mL}$, TPA $0.1 \mu \mathrm{g} / \mathrm{mL}$, and metal mixture (As $2 \mu \mathrm{M}, \mathrm{Cd} 2 \mu \mathrm{M}$, and Pb $5 \mu \mathrm{M}$ ); ${ }^{\text {p percentage with }}$ respect to controls; ${ }^{c}$ two experiments with three biological replicates; ${ }^{d}$ transforming potential (TP) calculated as number of transformed foci type III per dish/surviving cells at corresponding sampling day. Statistical analysis, Student's $t$-test $P$ value $*<0.05, * *<0.01$, and $* * *<0.001$.

Interactions between $\mathrm{As}, \mathrm{Cd}$, and $\mathrm{Pb}$ enhance the risk of cancer in certain human populations. However, the carcinogenic mechanisms associated with these metal mixtures have been poorly studied. Numerous possible mechanisms of action have been proposed: oxidative stress inductions, genotoxicity, DNA repair inhibition, and gene expression changes [13]. Among these proposed mechanisms, oxidative stress is commonly observed in in vivo and in vitro systems during exposure to these metals as mixture [4]. However, several studies suggest that certain metal-metal interactions inhibit carcinogenic activity [14]. Because humans are continually exposed to complex metal mixtures at low doses, it is necessary to determine the mechanism underlying the transformation process.

Cell transformation is a hallmark of carcinogenic activity [15]. There are two general categories of transformation systems based on the target cells used for the assay: diploid cells with limited in vitro life span (such as Syrian Hamster 
TABLE 2: Transforming potential through promotion phase.

\begin{tabular}{|c|c|c|c|c|c|}
\hline \multirow[b]{2}{*}{ Day } & \multicolumn{5}{|c|}{ Promotion Phase } \\
\hline & Treatment $^{\mathrm{a}}$ & Viability $(\%)^{\mathrm{b}}$ & $\begin{array}{l}\text { Dish with foci/dish } \\
\text { scored }^{c}\end{array}$ & $\begin{array}{l}\text { No. of transformed } \\
\text { foci/dish }\end{array}$ & $\mathrm{TP}^{\mathrm{d}}$ \\
\hline \multirow{5}{*}{11} & Control & $100 \pm 0.5$ & $4 / 6$ & $1.8 \pm 0.05$ & $1 \pm 0.27$ \\
\hline & $\mathrm{MNNG}+\mathrm{TPA}$ & $77 \pm 19.1^{*}$ & $6 / 6$ & $62.25 \pm 9.9^{* * *}$ & $61.6 \pm 9.8^{* * *}$ \\
\hline & Metal mixture + TPA & $57 \pm 15.8^{*}$ & $6 / 6$ & $33.75 \pm 11.6^{* * *}$ & $62 \pm 21.3^{* * *}$ \\
\hline & MNNG + Meta mixture & $9 \pm 0.66^{* * *}$ & $6 / 6$ & $23 \pm 7.7^{* * *}$ & $70.5 \pm 23.8^{* * *}$ \\
\hline & Metal mixture + metal mixture & $17 \pm 0.3^{* * *}$ & $6 / 6$ & $29.5 \pm 5.7^{* * *}$ & $78.5 \pm 15.1^{* * *}$ \\
\hline \multirow{5}{*}{16} & Control & $100 \pm 0.0$ & $4 / 6$ & $1.8 \pm 0.05$ & $1 \pm 0.27$ \\
\hline & MNNG + TPA & $100 \pm 11.5$ & $6 / 6$ & $62.25 \pm 9.9^{* * *}$ & $67.9 \pm 10.8^{* * *}$ \\
\hline & Metal mixture + TPA & $100 \pm 18.5$ & $6 / 6$ & $33.75 \pm 11.6^{* * *}$ & $25.1 \pm 8.6^{* * *}$ \\
\hline & MNNG + metal mixture & $31 \pm 8.9^{* *}$ & $6 / 6$ & $23 \pm 7.7^{* * *}$ & $38.5 \pm 13^{* * *}$ \\
\hline & Metal mixture + metal mixture & $30 \pm 8^{* * *}$ & $6 / 6$ & $29.5 \pm 5.7^{* * *}$ & $55.2 \pm 10.6^{* * *}$ \\
\hline \multirow{5}{*}{21} & Control & $100 \pm 0.0$ & $4 / 6$ & $1.8 \pm 0.05$ & $1 \pm 0.27$ \\
\hline & $\mathrm{MNNG}+\mathrm{TPA}$ & $77 \pm 0.5^{* * *}$ & $6 / 6$ & $62.25 \pm 9.9^{* * *}$ & $42.6 \pm 6.8^{* * *}$ \\
\hline & Metal mixture + TPA & $88 \pm 2.2^{* *}$ & $6 / 6$ & $33.75 \pm 11.6^{* * *}$ & $11.7 \pm 4^{*}$ \\
\hline & MNNG + metal mixture & $76 \pm 0.05^{* * *}$ & $6 / 6$ & $23 \pm 7.7^{* * *}$ & $13.6 \pm 4.6^{*}$ \\
\hline & Metal mixture + metal mixture & $31 \pm 6.9^{* * *}$ & $6 / 6$ & $29.5 \pm 5.7^{* * *}$ & $50.5 \pm 9.7^{* * *}$ \\
\hline
\end{tabular}

${ }^{\mathrm{a}}$ Treatments were added at concentrations of MNNG $0.5 \mu \mathrm{g} / \mathrm{mL}$, TPA $0.1 \mu \mathrm{g} / \mathrm{mL}$, and metal mixture (As $2 \mu \mathrm{M}, \mathrm{Cd} 2 \mu \mathrm{M}$, and Pb $5 \mu \mathrm{M}$ ); ${ }^{\mathrm{b}}$ percentage with respect to controls; ${ }^{c}$ two experiments with three biological replicates; ${ }^{d}$ transforming potential (TP) calculated as nmber of transformed foci type III per dish/surviving cells at corresponding sampling day. Statistical analysis, Student's $t$-test $P$ value $*<0.05, * *<0.01$ and ${ }^{* * *}<0.001$.

TABLE 3: Pearson's correlation between oxidative and antioxidant markers that influence transforming potential (TP).

\begin{tabular}{|c|c|c|c|c|c|c|c|}
\hline $\begin{array}{l}\text { Pearson's correlation } \\
\text { Correlation coefficient }(r)\end{array}$ & ROS & LPx & Genotoxicity & SOD activity & $\begin{array}{l}\text { Catalase } \\
\text { activity }\end{array}$ & TAC & Viability \\
\hline $\mathrm{TP}^{\mathrm{a}}$ & $0.436^{*}$ & 0.071 & -0.046 & 0.216 & 0.219 & 0.155 & $-0.753^{* *}$ \\
\hline $\mathrm{ROS}^{\mathrm{b}}$ & & $0.730^{* *}$ & 0.209 & $0.754^{* *}$ & $0.881^{* * *}$ & $0.835^{* * *}$ & $-0.539^{*}$ \\
\hline$L P x^{c}$ & & & $0.453^{*}$ & $0.909^{* * *}$ & $0.833^{* * *}$ & $0.873^{* * *}$ & -0.282 \\
\hline Genotoxicity & & & & $0.582^{*}$ & $0.445^{*}$ & 0.149 & -0.001 \\
\hline SOD $^{\mathrm{d}}$ activity & & & & & $0.848^{* * *}$ & $0.805^{* * *}$ & $-0.439^{*}$ \\
\hline Catalase activity & & & & & & $0.782^{* * *}$ & -0.429 \\
\hline $\mathrm{TAC}^{\mathrm{e}}$ & & & & & & & -0.398 \\
\hline
\end{tabular}

Values represent correlation coefficient $(r)$ and $P$ values $* P<0.05,{ }^{*} P<0.001,{ }^{* * *} P<0.0001 .{ }^{\mathrm{a}} \mathrm{TP}$ : transforming potential; ${ }^{\mathrm{b}} \mathrm{ROS}$ : reactive oxygen species; ${ }^{\mathrm{c}} \mathrm{LPx}$ : lipid peroxidation; ${ }^{\mathrm{d}} \mathrm{SOD}$ : superoxide dismutase; ${ }^{\mathrm{e}} \mathrm{TAC}$ : total antioxidant capacity.

Embryos) and immortalized aneuploid cell lines (such as $\mathrm{BALB} / \mathrm{c} 3 \mathrm{~T} 3$ and $\mathrm{C} 3 \mathrm{H} / 10 \mathrm{~T} 1 / 2$ cells) [16]. The most commonly employed target cells include BALB/c 3T3 A31-11 cells. The initiation and promotion of carcinogenesis are commonly studied in BALB/c 3T3 A31-1-1 cells [16-19]. Individually, the transformation capacity of $\mathrm{As}, \mathrm{Cd}$, and $\mathrm{Pb}$ has been tested previously in these cells; both As and $\mathrm{Cd}$ give a positive response, whereas $\mathrm{Pb}$ does not display transformation $[16,20-22]$. The aim of this work was to evaluate the transforming potential of the metal mixture $\left(2 \mu \mathrm{M} \mathrm{NaAsO}{ }_{2}+2 \mu \mathrm{M} \mathrm{CdCl}_{2}+5 \mu \mathrm{M} \mathrm{Pb}\left(\mathrm{C}_{2} \mathrm{H}_{3} \mathrm{O}_{2}\right)_{2} \cdot 3 \mathrm{H}_{2} \mathrm{O}\right)$ at relevant epidemiological concentrations, similar to those found in occupational exposure individuals [23-25], because has not been tested in this model.

In the present study we evaluated the role of reactive oxygen species and the antioxidant barrier in the development of oxidative stress damage through transforming processes.
This process was examined during the initiation and promotion phases of the two-step transformation model in BALB/C 3T3 A31-1-1 cells. The transforming potential of the metals mixture as initiator and/or promoter was also determined. We found that oxidative stress plays an important role in transformation induced by the metal mixture and is most prominent during the promotion phase of cell transformation.

\section{Material and Methods}

2.1. Chemicals. Sodium meta-arsenite $\left(\mathrm{NaAsO}_{2}\right.$, purity $100 \%)$, cadmium chloride $\left(\mathrm{CdCl}_{2}\right.$, purity $\left.99.5 \%\right), 12$-O-tetradecanoylphorbol-13-acetate (TPA), n-methyl-n-nitrosoguanidine (MNNG), 6-hydroxy-2,5,7,8-tetramethylchromane-2-carboxylic acid (Trolox), rhodamine 123 and dihydrorhodamine 123, were purchased from the Aldrich 


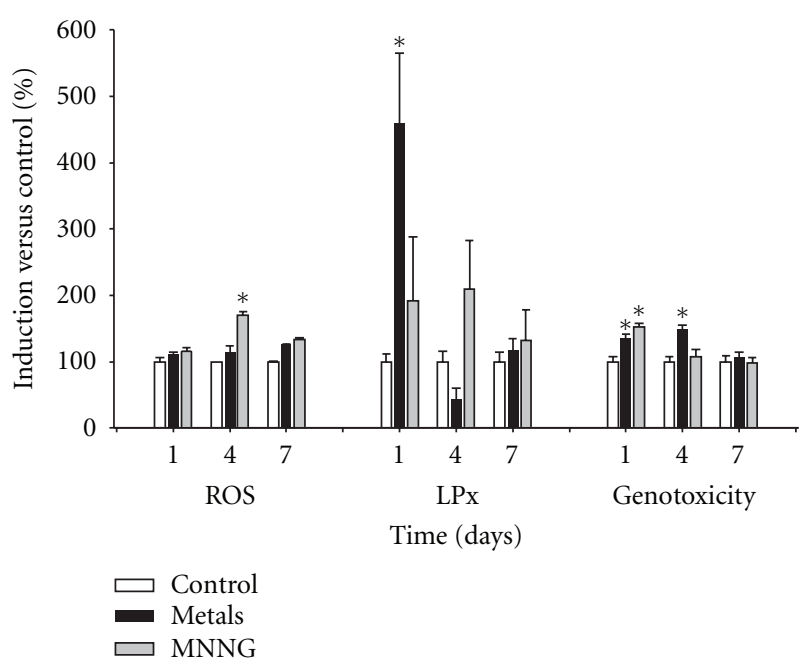

FIGURE 2: Effects of the metal mixture through initiation phase of transformation process, oxidative damage markers. Balb/c 3T3 cells were exposed to an initiator stimuli, metal mixture $(2 \mu \mathrm{M}$ $\mathrm{NaAsO}_{2}, 2 \mu \mathrm{M} \mathrm{CdCl}_{2}$, and $\left.5 \mu \mathrm{M} \mathrm{Pb}\left(\mathrm{C}_{2} \mathrm{H}_{3} \mathrm{O}_{2}\right)_{2} \cdot 3 \mathrm{H}_{2} \mathrm{O}\right)$ or $\mathrm{MNNG}$ (positive initiator), on day 1 . Samplings were on days 1 , after 4 hours of initiator exposure, and on days 4 and 7 before changing medium. Data represent the mean of 3 individual experiments performed by triplicate. We evaluated the generation of reactive oxygen species (ROS) using dihydrorhodamine-123 oxidation. Lipid peroxidation (LPx) was assessed using the thiobarbituric acid method, and genotoxicity was determined using the alkaline comet assay. ANOVA and Student's $t$-test; ${ }^{*} P<0.05$ versus control bars.

Chemical Co. (Milwaukee, Wis/USA). Lead acetate $\left(\mathrm{Pb}\left(\mathrm{C}_{2} \mathrm{H}_{3} \mathrm{O}_{2}\right)_{2} \cdot 3 \mathrm{H}_{2} \mathrm{O}\right.$, purity $\left.99.9 \%\right)$, insulin-transferrinselenium-A (ITS-A), and 1,1,3,3-tetraethoxypropane were purchased from J. T. Baker (México), GIBCO/Invitrogen (NY, USA) and Fluka Chemie Co. (USA), respectively.

2.2. Cell Culture. The morphological transformation experiments were performed using BALB/3T3 A31-1-1 clonal cells (ATCC). Cells were grown in Dulbecco's modified Eagle's minimum essential medium (DMEM) supplemented with $10 \%$ FBS in a humidified incubator under 95\% air and $5 \% \mathrm{CO}_{2}$. Cells were subcultured before reaching confluence, usually twice per week. Additional media used during the promotion stage of the transformation assay consisted of the following: Dulbecco's modified Eagle's minimum essential medium (DMEM) supplemented with 2\% FBS and $1 \%$ ITS-A $(10 \mathrm{mg} / \mathrm{mL}$ insulin, $5.5 \mathrm{mg} / \mathrm{mL}$ transferring, and $0.0067 \mathrm{mg} / \mathrm{mL}$ sodium selenite). All media were obtained from the GIBCO/Invitrogen (NY, USA).

2.3. Transformation Assay. The transformation assay was performed as described previously with slight modifications [22]. The transformation protocol consisted in 25 days, divided into two phases: initiation phase between days 1 to 7 and promotion between days 7 to 25. BALB/c 3T3 A31 cells were plated at a density of $5 \times 10^{5}$ cells per $100 \mathrm{~mm}$ dish in DMEM medium supplemented with 10\% FBS. After

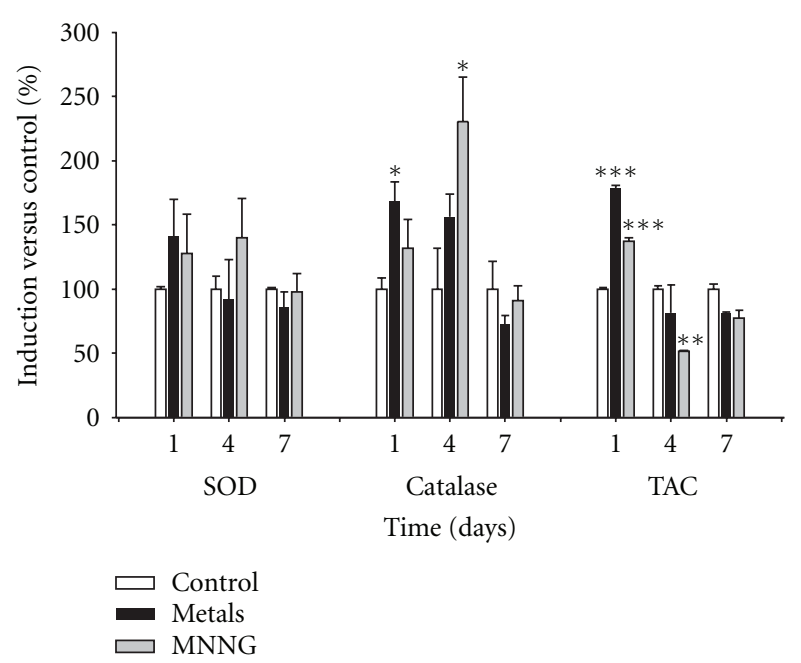

FIGURE 3: Effects of the metal mixture through initiation phase of transformation process, antioxidant activity markers. Balb/c 3T3 cells were exposed to initiator stimuli, metal mixture $(2 \mu \mathrm{M}$ $\mathrm{NaAsO}_{2}, 2 \mu \mathrm{M} \mathrm{CdCl}$, and $\left.5 \mu \mathrm{M} \mathrm{Pb}\left(\mathrm{C}_{2} \mathrm{H}_{3} \mathrm{O}_{2}\right)_{2} \cdot 3 \mathrm{H}_{2} \mathrm{O}\right)$ or MNNG (positive initiator), on day 1 . Samplings were on days 1 , after 4 hours of initiator exposure, and on days 4 and 7 before changing medium. Data represent the mean of 3 individual experiments performed by triplicate. Antioxidant activity is represented as a percentage with respect to control values. Superoxide dismutase (SOD) and catalase activities were evaluated using spectrophotometric assays, and the total antioxidant capacity (TAC) was assessed by the $\mathrm{ABTS}^{\circ}+$ radical method (ANOVA and Student's $t$-test; ${ }^{*} P<0.05,{ }^{* *} P<$ $0.001,{ }^{* * *} P<0.0001$ versus control bars).

$48 \mathrm{~h}$ incubation on day 1 , subconfluent cells were exposed to the metal mixture $\left(2 \mu \mathrm{M} \mathrm{NaAsO}_{2}, 2 \mu \mathrm{M} \mathrm{CdCl}_{2}\right.$, and $5 \mu \mathrm{M}$ $\left.\mathrm{Pb}\left(\mathrm{C}_{2} \mathrm{H}_{3} \mathrm{O}_{2}\right)_{2} \cdot 3 \mathrm{H}_{2} \mathrm{O}\right)$ or MNNG $(0.5 \mu \mathrm{g} / \mathrm{mL})$, as initiators. The media were removed 4 hours later, and the cells for initiation screening were replated at a density of $1 \times 10^{3}$ cells per $60-\mathrm{mm}$ dish. On day 4 , the media were replenished for all treatments and controls. On day 7, the dishes were replenished with medium supplemented with $1 \%$ ITS-A and $2 \%$ FBS. The metal mixture or TPA $(0.1 \mu \mathrm{g} / \mathrm{mL})$ was then added as promoters. These media and treatments with metal mixture or TPA were replenished on days 11 and 14. In days $9,16,18$, and 21 , the cells were reseeded only in fresh media DMEM $+1 \%$ ITS-A $+2 \%$ FBS. On day 25 , the cells were fixed with ethanol and stained with the Giemsa solution (see Figure 1). To examine the initiating effects of metals, cells were exposed to the metal mixture during the initiation stage and then treated with TPA during the promotion stage. To determine promotional effect, cells were treated with MNNG as initiator and exposed to the metal mixture during the promotion stage. In addition, the effects of metal mixture were examined as initiator and promoter stimuli. Treatments with MNNG as an initiator and TPA as a promoter were used as positive controls for cell transformation [18]; also, both were tested individually. The study groups will be mentioned as initiator/promoter. Samples used for analysis of the initiation phase were collected on day 1 after 4 hours of treatment and on days 4 and day 7 before the promoter treatment was started (Figure 1). Promotion samples were 


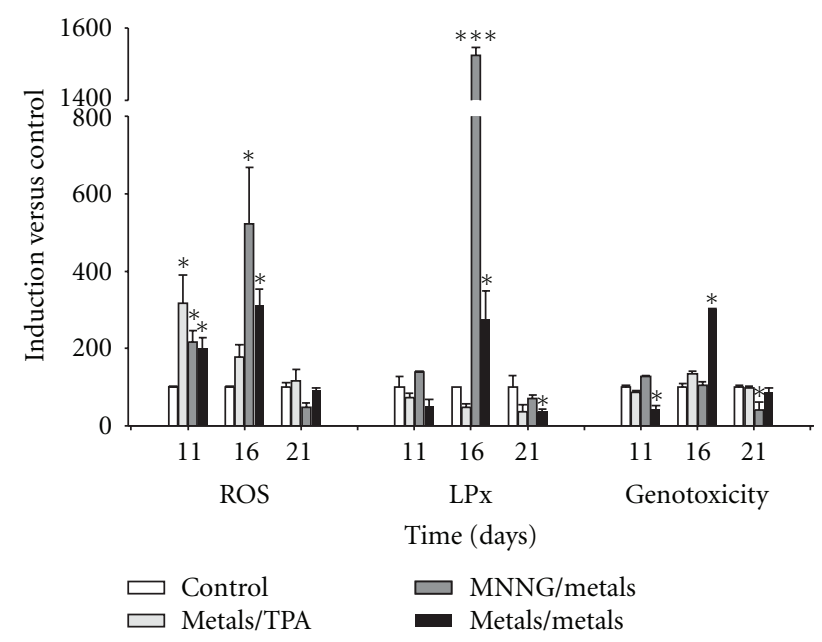

Figure 4: Effects of the metal mixture $\left(2 \mu \mathrm{M} \mathrm{NaAsO} 2,2 \mu \mathrm{M} \mathrm{CdCl}_{2}\right.$, and $\left.5 \mu \mathrm{M} \mathrm{Pb}\left(\mathrm{C}_{2} \mathrm{H}_{3} \mathrm{O}_{2}\right)_{2} \cdot 3 \mathrm{H}_{2} \mathrm{O}\right)$ through promotion phase of transformation process, oxidative damage markers. Balb/c 3T3 cells were exposed 4 hours to initiator stimuli, metal mixture or MNNG (positive initiator), on day 1 and promoter stimuli, metal mixture or TPA (positive promoter), on days 7, 11, and 14. Samplings were on days 11, 16, and 21 of the transformation protocol for monitoring promotion phase. Data represent the mean of 3 individual experiments performed by triplicate. We evaluated the generation of reactive oxygen species (ROS) using dihydrorhodamine-123 oxidation. Lipid peroxidation (LPx) was assessed using the thiobarbituric acid method, and genotoxicity was determined using the alkaline comet assay. ANOVA and Student's $t$-test; ${ }^{*} P<0.05,{ }^{* * *} P<0.0001$ versus control bars.

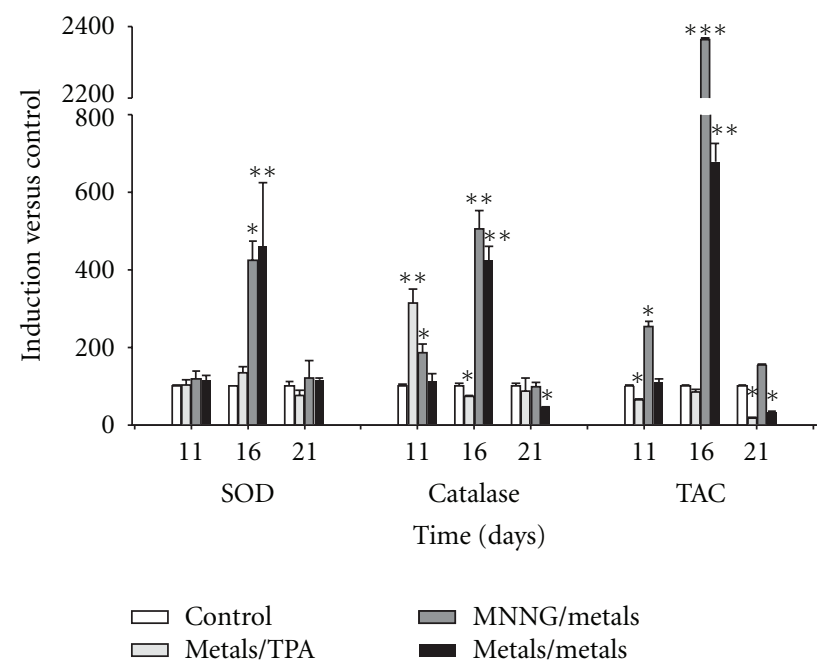

FIGURE 5: Effects of the metal mixture $\left(2 \mu \mathrm{M} \mathrm{NaAsO}, 2 \mu \mathrm{M} \mathrm{CdCl}_{2}\right.$, and $\left.5 \mu \mathrm{M} \mathrm{Pb}\left(\mathrm{C}_{2} \mathrm{H}_{3} \mathrm{O}_{2}\right)_{2} \cdot 3 \mathrm{H}_{2} \mathrm{O}\right)$ through promotion phase of transformation process, antioxidant activity markers. Balb/c 3T3 cells were exposed 4 hours to initiator stimuli, metal mixture or MNNG (positive initiator), on day 1 and promoter stimuli, metal mixture or TPA (positive promoter), on days 7, 11, and 14. Samplings were on days 11, 16, and 21 of the transformation protocol for monitoring promotion phase. Data represent the mean of 3 individual experiments performed by triplicate. Antioxidant activity is represented as a percentage with respect to control values. Superoxide dismutase (SOD) and catalase activities were evaluated using spectrophotometric assays, and the total antioxidant capacity (TAC) was assessed by the ABTS + radical $^{\circ}$ method (ANOVA and Student's $t$-test; ${ }^{*} P<0.05,{ }^{*} P<0.001,{ }^{* * *} P<0.0001$ versus control bars).

obtained on days 11, 16, and 21 (Figure 1). Transformed foci type III were scored according to the following criteria, which discriminate these foci based on four morphological characteristics: (1) foci of more than $2 \mathrm{~mm}$ in diameter, (2) deep basophilic staining, (3) dense multilayering of cells, and (4) random orientation of cells at the edge of the foci [16, $18,21,22]$. Data were analyzed using an optimized model as described by Ponti et al. [26]. To evaluate the transforming potential (TP), we count the number of transformed foci type III per dish obtained for each experimental condition and adjust it with respect to the number of surviving cells at each sampling day.

2.4. Viability. Cell viability was measured by the dual stain fluorescein diactetate (FDA) method as described by Rojas et al. [27]. Briefly, the cells were mixed with a fluorochrome 


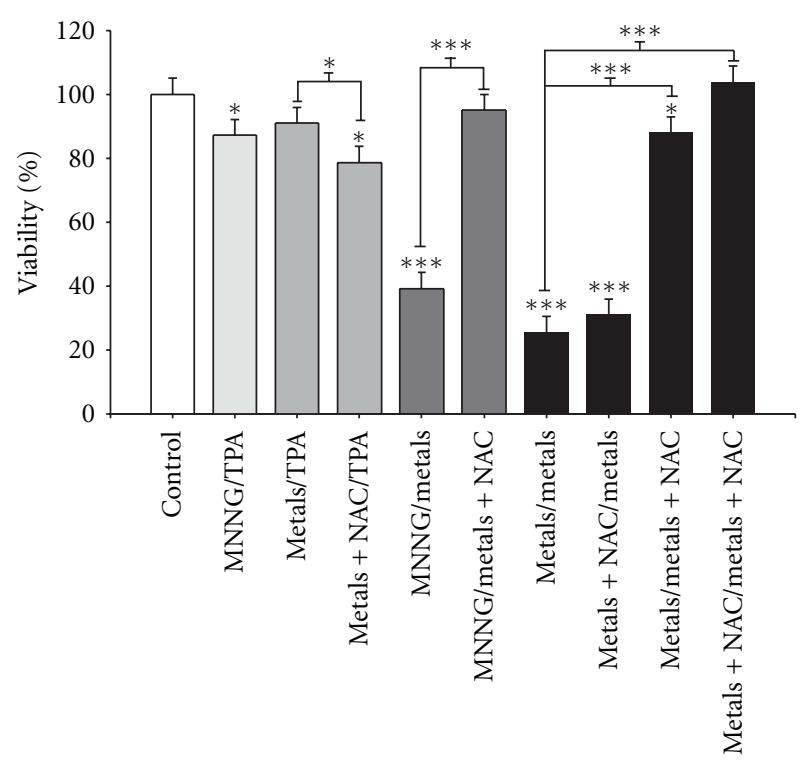

FIGURE 6: Influence of $N$-acetyl-cysteine (NAC) on metal-mixtureinduced transformation, cell viability determination. Cells were cotreated with $10 \mathrm{mM} \mathrm{NAC}$ and the metal mixture $\left(2 \mu \mathrm{M} \mathrm{NaAsO}_{2}\right.$, $2 \mu \mathrm{M} \mathrm{CdCl}$, and $\left.5 \mu \mathrm{M} \mathrm{Pb}\left(\mathrm{C}_{2} \mathrm{H}_{3} \mathrm{O}_{2}\right)_{2} \cdot 3 \mathrm{H}_{2} \mathrm{O}\right)$; samples were collected on day 16. Data represent the mean of three independent experiments performed in triplicate. Cell viability is presented as the percentage with respect to control values, as determined by the metabolic dual stain. ANOVA and Student's $t$-test ${ }^{*} P<0.05$, *** $P<0.0001$.

TABLE 4: Multivariate analysis of markers related with transforming potential (TP).

\begin{tabular}{lcccc}
\hline $\begin{array}{l}\text { Multiple linear } \\
\text { regression }\end{array}$ & Coefficient & $\begin{array}{c}\text { Standard } \\
\text { error }\end{array}$ & $P$ value & VIF $^{\mathrm{a}}$ \\
\hline ROS $^{\mathrm{b}}$ & 0.183 & 0.076 & 0.037 & $8.545^{*}$ \\
LPx $^{\mathrm{c}}$ & 0.023 & 0.034 & 0.506 & 12.405 \\
Genotoxicity & -0.006 & 0.096 & 0.948 & 3.346 \\
SOD $^{\text {d activity }}$ & 0.008 & 0.096 & 0.934 & 12.940 \\
Catalase activity & -0.112 & 0.068 & 0.132 & 8.732 \\
TAC & -0.028 & 0.018 & 0.149 & 10.827 \\
Viability & -0.373 & 0.123 & 0.013 & $1.926^{*}$ \\
\hline
\end{tabular}

${ }^{a}$ VIF: variance inflation factor; ${ }^{b} \mathrm{ROS}$ : reactive oxygen species; ${ }^{\mathrm{c}} \mathrm{LPx}$ : lipid peroxidation; ${ }^{\mathrm{d} S O D}$ : superoxide dismutase; ${ }^{\mathrm{e} T A C}$ : total antioxidant capacity. ${ }^{*} P<0.05$.

solution containing $0.02 \mu \mathrm{g} / \mathrm{mL}$ ethidium bromide and $0.015 \mu \mathrm{g} / \mathrm{mL}$ FDA. Cells were then analyzed under a fluorescence microscope (Olympus BMX-60 with a UM61002 filter); green-stained cells were identified as live, while redstained cells were identified as death cells. One hundred randomly chosen cells were evaluated per condition, and the results are expressed as percentages.

2.5. Reactive Oxygen Species (ROS). The dihydrorhodamine 123 technique is based on the reactive-oxygen-species(ROS-) dependent oxidation of dihydrorhodamine-123 to rhodamine-123 [28]. Briefly, $100 \mu \mathrm{L}$ aliquots of the harvested

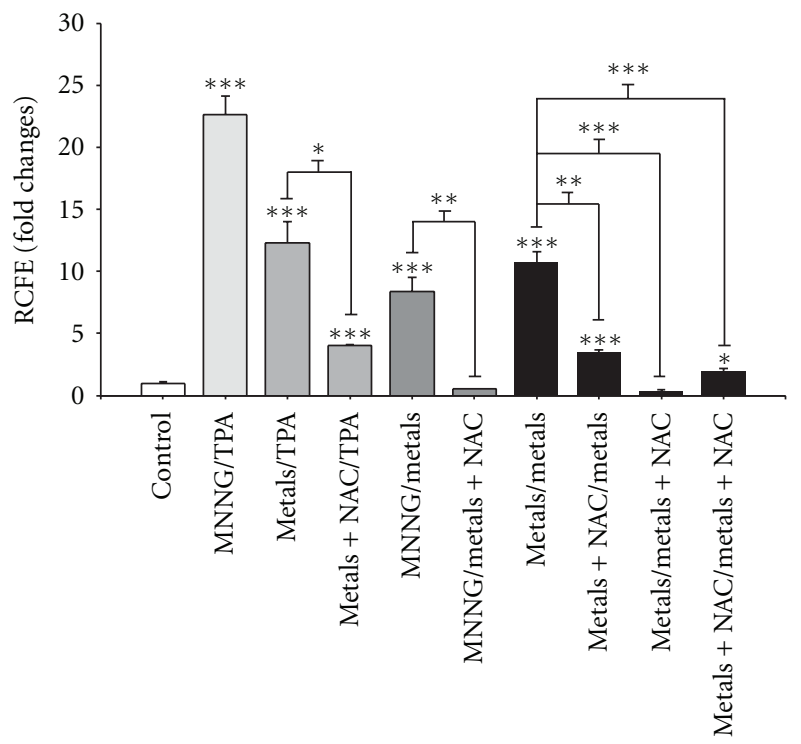

Figure 7: Influence of $N$-acetyl-cysteine (NAC) on metal-mixtureinduced transformation, number of transformation foci per dish. Cells were cotreated with $10 \mathrm{mM}$ NAC and the metal mixture $(2 \mu \mathrm{M}$ $\mathrm{NaAsO}_{2}, 2 \mu \mathrm{M} \mathrm{CdCl}$, and $\left.5 \mu \mathrm{M} \mathrm{Pb}\left(\mathrm{C}_{2} \mathrm{H}_{3} \mathrm{O}_{2}\right)_{2} \cdot 3 \mathrm{H}_{2} \mathrm{O}\right)$; samples were collected on day 25. Data represent the mean of three independent experiments performed in triplicate. Transformation is presented as the fold change with respect to control values. This value corresponds to the number of foci/dish in the experimental condition over the number of foci/dish in control samples. The results are presented as a percentage with respect to control values. ANOVA and Student's $t$-test ${ }^{*} P<0.05,{ }^{* *} P<0.001,{ }^{* * *} P<$ 0.0001 .

samples were collected and centrifuged at $1200 \mathrm{rpm}$ for 5 minutes. The supernatant was then discarded, and $180 \mu \mathrm{L}$ of buffer A $\left(140 \mathrm{mM} \mathrm{NaCl}, 5 \mathrm{mM} \mathrm{KCl}, 0.8 \mathrm{mM} \mathrm{MgSO}_{4} 7 \mathrm{HO}\right.$, $1,8 \mathrm{mM} \mathrm{CaCl}_{2}, 5 \mathrm{mM}$ glucose and $15 \mathrm{mM}$ HEPES) and $20 \mu \mathrm{L}$ of dihydrorhodamine $123(1 \mu \mathrm{M})$ were added. The absorbance of the rhodamine 123 formed was measured at $505 \mathrm{~nm}$ using an ELISA spectrophotometer (Bio-Rad Model 550) and interpolated in a curve of rhodamine 123 in concentrations of $0-10 \mu \mathrm{M}$.

2.6. Lipid Peroxidation (LPx). The thiobarbituric acid method was used to measure the concentration of malondialdehyde (MDA) [29]. A $100 \mu \mathrm{L}$ aliquot was added to $100 \mu \mathrm{L}$ of trichloroacetic acid $(10 \% \mathrm{w} / \mathrm{v})$ and centrifuged at $3000 \times \mathrm{g}$ for 10 minutes. The supernatant was then added to $1 \mathrm{~mL}$ of the thiobarbituric acid reagent $(0.375 \%)$, and the mixture was heated at $92^{\circ} \mathrm{C}$ for 45 minutes. The absorbance of the thiobarbituric acid-MDA complex was measured at $532 \mathrm{~nm}$ using an ELISA spectrophotometer (Bio-Rad Model 550). Data were interpolated onto a concentration curve of $1,1,3,3$ tetraethoxypropane ranging from 0 to $10 \mathrm{nM}$.

2.7. Genotoxicity. Single-Cell Gel Electrophoresis (SCGE) Assay. Ten microliters of the cell suspension (10,000-15,000 cells) was mixed with $75 \mu \mathrm{L}$ of a $0.5 \% \mathrm{LMP}$ agarose solution $(0.36 \%$ final $)$ and loaded onto microscope slides prelayered 


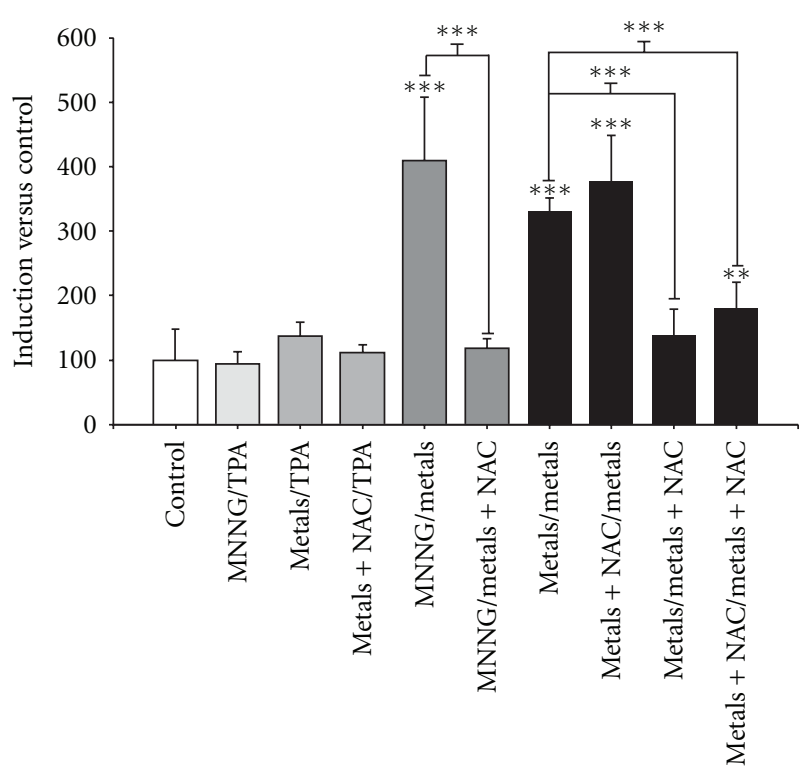

FIGURE 8: Influence of $N$-acetyl-cysteine (NAC) on metal-mixtureinduced transformation, lipid peroxidation. Cells were cotreated with $10 \mathrm{mM}$ NAC and the metal mixture $(2 \mu \mathrm{M} \mathrm{NaAsO}, 2 \mu \mathrm{M}$ $\mathrm{CdCl}_{2}$, and $\left.5 \mu \mathrm{M} \mathrm{Pb}\left(\mathrm{C}_{2} \mathrm{H}_{3} \mathrm{O}_{2}\right)_{2} \cdot 3 \mathrm{H}_{2} \mathrm{O}\right)$; samples were collected on day 16. Data represent the mean of three independent experiments performed in triplicate. LPx was measured as an oxidative stress marker. The results are presented as a percentage with respect to control values, as determined by the thiobarbituric acid method (ANOVA and Student's $t$ test ${ }^{* *} P<0.001,{ }^{* * *} P<0.0001$ ).

with $150 \mu \mathrm{L}$ of $0.5 \%$ normal melting point agarose. The SCGE assay was performed as described by Vega et al. [30]. Briefly, after incubation with lysis buffer $(2.5 \mathrm{M} \mathrm{NaCl}$, $100 \mathrm{mM}$ EDTA, $10 \mathrm{mM}$ Tris, $\mathrm{pH}$ 10, supplemented with $10 \%$ DMSO and $1 \%$ Triton $\mathrm{X}-100$ ) at $4{ }^{\circ} \mathrm{C}$ for at least $1 \mathrm{~h}$, the slides were placed in a horizontal electrophoresis chamber containing running buffer solution ( $300 \mathrm{mM} \mathrm{NaOH}, 1 \mathrm{mM}$ EDTA, $\mathrm{pH}>13)$. The slides remained in the electrophoresis buffer for $10 \mathrm{~min}$ to allow the DNA to unwind. Electrophoresis was performed for $10 \mathrm{~min}$ at $300 \mathrm{~mA}$ and $25 \mathrm{~V}(\sim 0.8 \mathrm{~V} / \mathrm{cm})$, and all technical steps were conducted using very dim indirect light. After electrophoresis, the slides were gently removed and rinsed with neutralization buffer ( $0.4 \mathrm{M}$ Tris, $\mathrm{pH}$ 7.5) at room temperature for $15 \mathrm{~min}$. The slides were dehydrated with $100 \%$ ethanol ( $15 \mathrm{~min}$ ), after which they were air-dried. Ethidium bromide ( $20 \mu \mathrm{L}$ of a $0.2 \mu \mathrm{g} / \mathrm{mL}$ solution) was added to each slide, and a coverslip was placed on the gel. Individual cells were visualized at 20x magnification using an Olympus BX-60 microscope with fluorescence attachments (515$560 \mathrm{~nm}$ excitation filter, $590 \mathrm{~nm}$ barrier filter). Images were digitized and analyzed using KOMET v.31 software (Kinetic Imaging), and the Olive tail moment (OTM) parameter was used to evaluate DNA damage (200 cells were scored for each condition).

2.8. Determination of Catalase Activity. Catalase activity was measured as described by Aebi [31]. Briefly, the cells were washed two or three times with sterile PBS containing protease inhibitors. The cells were sonicated for 10 cycles of
10 seconds each at $20 \mathrm{MHz}$. After sonication, the cells were centrifuged at $10,000 \mathrm{rpm}$ for 5 minutes at $4^{\circ} \mathrm{C}$. Catalase activity and the protein concentration were measured in the supernatant. To measure catalase activity, the absorbance of $100 \mu \mathrm{L}$ of supernatant was determined at $240 \mathrm{~nm}$ in phosphate buffer $(50 \mathrm{mM})$ at room temperature. After the addition of $20 \mathrm{mM} \mathrm{H}_{2} \mathrm{O}_{2}$, the absorbance was recorded every 15 seconds over a period of 1 minute. Data analysis was performed as described by Aebi [31].

2.9. Determination of Superoxide Dismutase (SOD) Activity. Superoxide dismutase activity was measured following the protocol proposed by Sun et al. [32]. This method is based on the competition between superoxide dismutase and tetrazolium blue for the superoxide radicals formed from the xanthine oxidase reaction. Cells were sonicated and centrifuged at $10,000 \mathrm{rpm}$ for 10 minutes at $4^{\circ} \mathrm{C}$. Next, $200 \mu \mathrm{L}$ of the supernatant was divided into two tubes containing $1.85 \mathrm{~mL}$ of the reaction $\mathrm{mix}(0.265 \mathrm{mM}$ xanthine, $0.53 \mathrm{mM}$ EDTA, $0.1325 \mathrm{mM}$ NBT, $883 \mathrm{mg} / \mathrm{mL}$ albumin, $353 \mathrm{mM} \mathrm{Na}_{2} \mathrm{CO}_{3}$ ). Fifty microliters of $50 \mathrm{mM}$ phosphate buffer (blank) was added to one tube, and $50 \mu \mathrm{L}$ of xanthine oxidase (2-2.5 U/ $\mathrm{mL}$ ) was added to the other tube. The tubes were incubated for 15 minutes, and then $500 \mu \mathrm{L}$ of a $\mathrm{CuCl}_{2}$ solution was added to stop the reaction. Two hundred microliters of the reaction mixture was added to a 96-well microplate, and the absorbance was measured at $560 \mathrm{~nm}$. The units of SOD were calculated as follows:

$$
\text { units of SOD }=\frac{\left[\mathrm{A}_{\text {reaction mix }}-\left(\mathrm{A}_{\text {sample }}-\mathrm{A}_{\mathrm{blank}}\right)\right]}{\left[\mathrm{A}_{\text {reaction mix }}(0.5 \%)\right]} .
$$

A unit of SOD is defined as the quantity of enzyme required to decrease the absorbance by $50 \%$.

2.10. Total Antioxidant Capacity (TAC). The total antioxidant capacity was measured as described by Erel [33] with modifications. This method is based on the reduction of the $\mathrm{ABTS}^{\bullet+}$ radical. $\mathrm{ABTS}^{\bullet+}$ is generated by an initial incubation with hydrogen peroxide in an acidic medium (final concentration of $\mathrm{ABTS}^{\bullet+}: 10 \mathrm{mM}$ ). Next, $5 \mu \mathrm{L}$ of the sample was mixed with $200 \mu \mathrm{L}$ of reagent 1 (0.4 M acetate buffer; ph 5.8) in a 96-well plate. Twenty microliters of reagent $2(30 \mathrm{mM}$ ABTS $^{*}$ in acetate buffer; $\mathrm{pH}$ 3.6) was then added to the mixture, and the absorbance was read before mixing $\mathrm{R} 1$ with R2 (blank). One final absorbance reading was obtained at the end of the $5 \mathrm{~min}$ incubation period at $740 \mathrm{~nm}$. The reaction rate was calibrated and interpolated on a curve of Trolox absorbance $(0-100 \mu \mathrm{M})$. The TAC measurement assay results were obtained as the Trolox equivalent/L.

\section{Results}

3.1. In Vitro Cell Transformation. The transforming potential of the metal mixture $\left(2 \mu \mathrm{M} \mathrm{NaAsO}{ }_{2}, 2 \mu \mathrm{M} \mathrm{CdCl}_{2}\right.$ and $5 \mu \mathrm{M}$ $\left.\mathrm{Pb}\left(\mathrm{C}_{2} \mathrm{H}_{3} \mathrm{O}_{2}\right)_{2} \cdot 3 \mathrm{H}_{2} \mathrm{O}\right)$ was determined based on an endpoint test which uses the number of foci per plate stained at day 25 of the assay, adjusted with the number of surviving cells at every sampling day per condition. Under this analysis we 


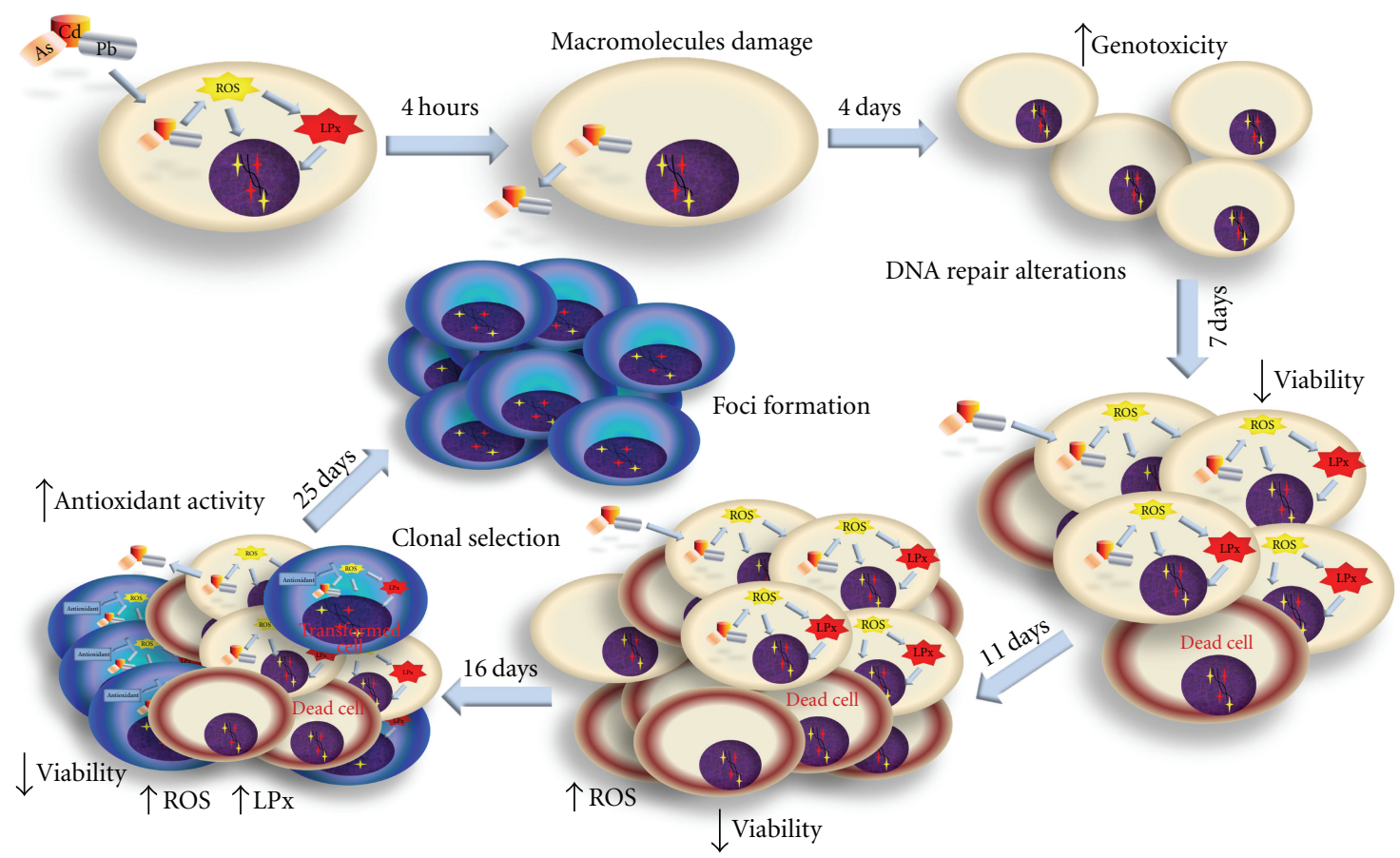

Figure 9: Scheme of metal mixture transformation process in Balb c/3T3. We show that damage to macromolecules (lipids and DNA) occurs the first day of initiation phase with no change in cell viability, suggesting that DNA repair systems may have been impaired by the metal mixture treatment $\left(2 \mu \mathrm{M} \mathrm{NaAsO}_{2}, 2 \mu \mathrm{M} \mathrm{CdCl}_{2}\right.$, and $\left.5 \mu \mathrm{M} \mathrm{Pb}\left(\mathrm{C}_{2} \mathrm{H}_{3} \mathrm{O}_{2}\right)_{2} \cdot 3 \mathrm{H}_{2} \mathrm{O}\right)$, in addition to the observed genotoxicity. During the promotion phase, clonal selection of the transformed cells was clearly observed, as evidenced by an increase in oxidative stress markers, induction of the antioxidant response, and loss of cell viability. Cells with various advantages survived, such as those with a high antioxidant capacity until foci formation.

present transforming potential (TP) data across initiation (Table 1) and promotion phase (Table 2) for all experimental conditions. The metal mixture demonstrated a high degree of transforming potential during both the initiation and the promotion phases of transformation. Punctually in Table 1 , metal mixture as initiator stimuli is the unique experimental condition that clearly shows positive TP in addition to positive control, MNNG/TPA (initiator/promoter), while metal mixture as promoter and metals/metals show TP statistically significant at day 7 . However through promotion phase (Table 2), TP was positive for all experimental conditions being greatest at day 11 of the transforming process. Across promotion phase, metal mixture as initiator treatment decreases TP, while metal mixture as promoter or both initiator and promoter increases TP, showing an additive behavior. Furthermore, the effects of metal mixture were higher than those observed for the positive controls (MNNG/TPA); also, neither MNNG nor TPA showed transforming capacity (data not shown).

3.2. Effects of the Metal Mixture on the Initiation Phase. Chemical carcinogenesis is a multistep process that involves morphological cell transformation, which measures the carcinogenic potential during both the initiation and the promotion phases [20,34]. We determined the mechanism by which the metal mixture affects oxidative stress during the initiation phase using samples from days 1, 4, and 7 (Figures 2 and 3$)$.
ROS generation was positive in day 4 of samples treated with MNNG. Lipid peroxidation and genotoxicity were observed after treatment with the metal mixture for four hours on day 1 . Genotoxicity was also induced on day 4, but neither lipid peroxidation nor genotoxicity was observed on day 7 (Figure 2).

After treatment with the metal mixture, catalase and total antioxidant capacity activation were detected on day 1 (Figure 3). These results indicate that the cells had undergone transformation with a concomitant decrease in viability (Table 1). Treatment-induced oxidative stress was suppressed by the cellular antioxidant response.

\subsection{Effects of the Metal Mixture on the Promotion Phase of} Transformation. The promotion phase of cellular transformation occurs after chronic exposure to a promoter agent. BALB/C 3T3 cells can be used as a model of this effect in the transformation protocol [35]. The effects of the metal mixture on oxidative stress during this stage were measured on days 11, 16, and 21 (Figures 4 and 5).

In all treatments, we observed a dramatic decrease in cell viability on day 11 (Table 2). However, on day 16, just the cells treated with the metal mixture/TPA (initiator/promoter) demonstrated recovery to control levels. On day 11, the transforming potential determined for every treatment was similar to that induced by the positive control. However, this effect decreased over time. On day 21 , the metal mixture 
promoter treatment induced transformation to a level similar to the TPA promoter treatment (Table 2).

Oxidative stress was determined based on the levels of measured reactive oxygen species, lipid peroxidation, and genotoxicity. These parameters were highly increased after treatment with the metal mixture during the promotion phase on day 16 . However, only ROS generation was detected on day 11 for every treatment (Figure 4).

Antioxidant activity was determined by measuring catalase and SOD activities, as well as TAC. These activities were highly increased on day 16 , but only catalase activity was increased on day 11 after treatment with the metal mixture/ TPA and MNNG/metal mixture (Figure 5). During the promotion phase, we observed a large elevation in oxidative stress markers (day 16), resulting in a decrease in cell viability at day 21 (Table 2 ). Those results suggest a cloning selection process for cells that have the capacity to resist oxidative stress.

3.4. Pearson Correlation Analysis and Multivariate Analysis. To determine the influence of oxidative stress on the transformation process, we performed a statistical analysis to evaluate the effects of treatment with the metal mixture during both the initiation and the promotion phases. Table 3 shows the relationship between oxidative markers and antioxidant response markers; however, only ROS and cell viability correlated with the transforming potential. We proceeded to study this relationship using multivariate analysis with multiple linear regression. A model was obtained for each variable; however, the transforming potential was predicted only by cell viability and ROS induction (Table 4 ). These results suggest that ROS influences transformation and viability via the generation of oxidative stress and challenging antioxidant response.

3.5. Influence of NAC on Transformation Induced by the Metal Mixture; Determination of Cell Viability, Transforming Capacity, and Lipid Peroxidation. N-Acetyl-cysteine (NAC) is a cysteine donor that promotes the reduction of glutathione (GSH). NAC acts as an antioxidant in chelation therapy for metal detoxification. Based on these characteristics, we performed a metals-NAC cotreatment in an attempt to block the metal-mixture-induced oxidative stress and transformation [36]. We coexposed the cells with $10 \mathrm{mM} \mathrm{NAC}$ and metal mixture $(2 \mu \mathrm{M} \mathrm{NaAsO}, 2 \mu \mathrm{M} \mathrm{CdCl} 2$ and $5 \mu \mathrm{M}$ $\left.\mathrm{Pb}\left(\mathrm{C}_{2} \mathrm{H}_{3} \mathrm{O}_{2}\right)_{2} \cdot 3 \mathrm{H}_{2} \mathrm{O}\right)$ across transformation protocol.

We determined the effects of NAC on cell viability and lipidperoxidation on day 16 of the protocol because this time point elicited the greatest induction of oxidative stress. A loss of cell viability was observed following NAC cotreatment as initiator stimuli and TPA as promoter treatment. However, viability recovery was observed in NAC cotreatment as promoter stimuli; these effects were similar to those determined for the controls (Figure 6).

NAC cotreatment, as initiator stimuli, did not affect lipid peroxidation; however, these treatments as promoter stimuli abolished metal-mixture-induced lipid peroxidation during the promotion phase (Figure 8).
Transformation was determined by measuring the foci number per dish on day 25 (Figure 7). NAC cotreatment diminished transformation when is administered as initiator, whereas NAC cotreatment abolished metal-mixture-induced transformation as promoter treatment. NAC cotreatment as initiator and promoter had an intermediate effect; it diminished the number of transformation foci (Figure 7). These results suggest that oxidative stress greatly influences the promotion phase but not the initiation phase; thus, a nonoxidation-stress mechanism must underlie the effects observed during the initiation phase.

\section{Discussion}

Numerous metals found in the environment have been classified as carcinogens [7-9]. Acute exposure to these metals is common; however, in smelter and recycling battery industries, people are exposed chronically to metal mixtures of $\mathrm{NaAsO}_{2}, \mathrm{CdCl}_{2}$, and $\mathrm{Pb}\left(\mathrm{C}_{2} \mathrm{H}_{3} \mathrm{O}_{2}\right)_{2} \cdot 3 \mathrm{H}_{2} \mathrm{O}$, having this kind of exposure as our particular interest [1, 23-25]. Several studies have been performed to find an interaction profile of this mixture suggesting an additive interaction in carcinogenic process $[5,6]$. In vitro cell transformation assays have shown a relatively high correlation to carcinogenicity bioassays; one of the most valuated models are Balb/c 3T3 cells, in which we can evaluate both initiator and promoter substances in transformation process [26]. Because cell transformation is an event that is related with this carcinogenic capacity, we evaluated whether a metal mixture of $2 \mu \mathrm{M}$ $\mathrm{NaAsO}_{2}, 2 \mu \mathrm{M} \mathrm{CdCl}_{2}$, and $5 \mu \mathrm{M} \mathrm{Pb}\left(\mathrm{C}_{2} \mathrm{H}_{3} \mathrm{O}_{2}\right)_{2} \cdot 3 \mathrm{H}_{2} \mathrm{O}$ could transform Balb/c 3T3 cells. These cells have recently been mentioned as good model to the study of mixtures [37]. We evaluated the effects of the mixture as initiator, promoter, and both and determined the role of oxidative stress in transformation process. Our results showed that metals mixtures $(2 \mu \mathrm{M} \mathrm{NaAsO}, 2 \mu \mathrm{M} \mathrm{CdCl}$, and $5 \mu \mathrm{M}$ $\left.\mathrm{Pb}\left(\mathrm{C}_{2} \mathrm{H}_{3} \mathrm{O}_{2}\right)_{2} \cdot 3 \mathrm{H}_{2} \mathrm{O}\right)$ produced transformation as both initiator and promoter (Tables 1 and 2), since other studies showed that single exposure to these metals could not produced transformation at the same concentrations except for cadmium. It appears that mixture enhances morphological transformation in this model $[16,21,22,38]$. Meanwhile, concerning transforming potential, which is a measure of the capacity of the cells to produce foci, we detect a strong effect when metal mixture was administered as promoter more than initiator, pointing out the relevance of this particular mixture in the carcinogenic process. Cadmium, on the other hand, has been proposed as promoter in the model by several authors $[21,25,26,34,39-42]$. This is in agreement with the idea that metal carcinogenic could be more related with promotion effects rather than initiation effects.

The primary variables that affected transformation were the generation of reactive oxygen species (ROS) and the loss of cell viability; these data support the clone selection theory [10] (Tables 3 and 4, Figures 6 and 7). We statistically analyzed the contribution of ROS, lipoperoxidation, genotoxicity, SOD activity, catalase activity, TAC, and viability with the transforming potential across initiation and promotion phases. However, only ROS generation and loss of cell 
viability correlated significantly with transformation (Tables 3 and 4). We summarize our observations of the phenomenon in Figure 9; we show that oxidative damage to macromolecules is induced during the initiation phase (Figure 2) with no change in cell viability (Table 1 ). Considering that DNA damage occurred during the first days of the initiation process (Figure 2), we suggest that the DNA repair system may have been impaired by the metal mixture treatment, in addition to the observed genotoxicity; these effects have been observed in other studies as well [43-46]. During the promotion phase, clonal selection of the transformed cells was clearly observed, as evidenced by an increase in oxidative stress markers (ROS generation), induction of the antioxidant response, and loss of cell viability on day 16 (Figures $2-5$, Table 2). Cells with various advantages survived, such as those with a high antioxidant capacity (Figure 5). These data agree with the results reported by Salnikow et al. [47], who determined that nickel-transformed Balb/c 3T3 cells demonstrate a high antioxidant capacity compared to nontransformed Balb/c 3T3 cells [47]. In addition, tumor cells possess an elevated antioxidant capacity $[48,49]$. The present results suggest that oxidative stress is involved in metalmixture-induced transformation, because elevated levels of oxidative markers were observed during both phases, and these effects induced clone selection of the transformed cells. To confirm these results, cotreatment of metal mixture $\left(2 \mu \mathrm{M} \mathrm{NaAsO}_{2}, 2 \mu \mathrm{M} \mathrm{CdCl}_{2}\right.$ and $\left.5 \mu \mathrm{M} \mathrm{Pb}\left(\mathrm{C}_{2} \mathrm{H}_{3} \mathrm{O}_{2}\right)_{2} \cdot 3 \mathrm{H}_{2} \mathrm{O}\right)$ with NAC was performed (Figures 6-9). This treatment abolished the observed transforming effects when it was performed as promoter treatment. However, the effect of the treatment was diminished when it was performed as initiator stimuli or both. These results suggest that a different mechanism may underlie the effects of the metal mixture during the initiation of transformation, and this mechanism may involve DNA damage, DNA repair alterations, or the regulation of gene expression. Nevertheless, during the promotion phase, the induction of oxidative stress plays an important and definitive role in metal-mixture-induced cell transformation. Our results suggest that oxidative stress induced by the metal mixture $\left(2 \mu \mathrm{M} \mathrm{NaAsO}, 2 \mu \mathrm{M} \mathrm{CdCl}_{2}\right.$ and $\left.5 \mu \mathrm{M} \mathrm{Pb}\left(\mathrm{C}_{2} \mathrm{H}_{3} \mathrm{O}_{2}\right)_{2} \cdot 3 \mathrm{H}_{2} \mathrm{O}\right)$ in Balb/c $3 \mathrm{~T} 3$ cells leads to clone selection.

\section{Acknowledgment}

S.-A. Martin is the recipient of a fellowship from the Consejo Nacional de Ciencia y Tecnología (CONACyT).

\section{References}

[1] L. Carrizales, I. Razo, J. I. Téllez-Hernández et al., "Exposure to arsenic and lead of children living near a copper-smelter in San Luis Potosi, Mexico: importance of soil contamination for exposure of children," Environmental Research, vol. 101, no. 1, pp. 1-10, 2006.

[2] D. S. Bae, C. Gennings, W. H. Carter Jr., R. S. H. Yang, and J. A. Campain, "Toxicological interactions among arsenic, cadmium, chromium, and lead in human keratinocytes," Toxicological Sciences, vol. 63, no. 1, pp. 132-142, 2001.
[3] C. de Burbure, J. P. Buchet, A. Leroyer et al., "Renal and neurologic effects of cadmium, lead, mercury, and arsenic in children: evidence of early effects and multiple interactions at environmental exposure levels," Environmental Health Perspectives, vol. 114, no. 4, pp. 584-590, 2006.

[4] G. Wang and B. A. Fowler, "Roles of biomarkers in evaluating interactions among mixtures of lead, cadmium and arsenic," Toxicology and Applied Pharmacology, vol. 233, no. 1, pp. 9299, 2008.

[5] ATSDR and CERCLA, Priority List of Hazardous Substances, Agency for Toxic Substances and Disease Registry, U.S. Department of Health and Human Services, 2007.

[6] ATSDR and CERCLA, Interaction Profile for: Arsenic, Cadmium, Chromium, and Lead, Agency for Toxic Substances and Disease Registry, U.S. Department of Health and Human Services, 2004.

[7] A. Aitio, L. Alessio, O. Axelson et al., "IARC monographs on the evaluation of carcinogenic risks to humans: beryllium, cadmium, mercury, and exposures in the glass manufacturing industry. Volume 58," IARC Monographs on the Evaluation of Carcinogenic Risks to Humans, vol. 58, pp. 119-237, 1993.

[8] IARC, "Arsenic in drinking water. Some drinking-water, disinfectants and contaminants, including arsenic," IARC Monographs on the Evaluation of Carcinogenic Risks to Humans, vol. 84, pp. 39-44, 2004.

[9] A. Anttila, P. Apostoli, J. A. Bond et al., "Inorganic and organic lead compounds," IARC Monographs on the Evaluation of Carcinogenic Risks to Humans, vol. 87, pp. 1-506, 2006.

[10] M. Valko, C. J. Rhodes, J. Moncol, M. Izakovic, and M. Mazur, "Free radicals, metals and antioxidants in oxidative stressinduced cancer," Chemico-Biological Interactions, vol. 160, no. 1, pp. 1-40, 2006.

[11] K. L. Cooper, K. J. Liu, and L. G. Hudson, "Enhanced ROS production and redox signaling with combined arsenite and UVA exposure: contribution of NADPH oxidase," Free Radical Biology and Medicine, vol. 47, no. 4, pp. 381-388, 2009.

[12] M. Ahamed and M. K. J. Siddiqui, "Low level lead exposure and oxidative stress: current opinions," Clinica Chimica Acta, vol. 383, no. 1-2, pp. 57-64, 2007.

[13] D. Beyersmann and A. Hartwig, "Carcinogenic metal compounds: recent insight into molecular and cellular mechanisms," Archives of Toxicology, vol. 82, no. 8, pp. 493-512, 2008.

[14] E. F. Madden, "The role of combined metal interactions in metal carcinogenesis: a review," Reviews on Environmental Health, vol. 18, no. 2, pp. 91-109, 2003.

[15] A. L. Meyer, "In vitro transformation assays for chemical carcinogens," Mutation Research, vol. 115, no. 3, pp. 323-338, 1983.

[16] Y. Kajiwara and S. Ajimi, "Verification of the BALB/c 3T3 cell transformation assay after improvement by using an ITESmedium," Toxicology in Vitro, vol. 17, no. 4, pp. 489-496, 2003.

[17] IARC/NCI/EPA Working Group, "Cellular and molecular mechanisms of cell transformation and standardization of transformation assays of established cell lines for the prediction of carcinogenic chemicals: overview and recommended protocols," Cancer Research, vol. 45, pp. 2395-2399, 1985.

[18] T. Tsuchiya and M. Umeda, "Relationship between exposure to TPA and appearance of transformed cells in MNNG-initiated transformation of BALC/c 3T3 cells," International Journal of Cancer, vol. 73, no. 2, pp. 271-276, 1997.

[19] T. Hartung, S. Bremer, S. Casati et al., "ECVAM's response to the changing political environment for alternatives: consequences of the European Union Chemicals and Cosmetics 
Policies," ATLA Alternatives to Laboratory Animals, vol. 31, no. 5, pp. 473-481, 2003.

[20] N. Keshava, G. Zhou, A. F. Hubbs, M. X. Ensell, and T. M. Ong, "Transforming and carcinogenic potential of cadmium chloride in BALB/c-3T3 cells," Mutation Research, vol. 448, no. 1, pp. 23-28, 2000.

[21] M. Z. Fang, W. Mar, and M. H. Cho, "Cadmium affects genes involved in growth regulation during two-stage transformation of Balb/3T3 cells," Toxicology, vol. 177, no. 2-3, pp. 253$265,2002$.

[22] T. Tsuchiya, T. Tanaka-Kagawa, H. Jinno et al., "Inorganic arsenic compounds and methylated metabolites induce morphological transformation in two-stage BALB/c $3 \mathrm{~T} 3$ cell assay and inhibit metabolic cooperation in V79 cell assay," Toxicological Sciences, vol. 84, no. 2, pp. 344-351, 2005.

[23] H. Merzenich, A. Hartwig, W. Ahrens et al., "Biomonitoring on carcinogenic metals and oxidative DNA damage in a crosssectional study," Cancer Epidemiology Biomarkers and Prevention, vol. 10, no. 5, pp. 515-522, 2001.

[24] J. G. Hengstler, U. Bolm-Audorff, A. Faldum et al., "Occupational exposure to heavy metals: DNA damage induction and DNA repair inhibition prove co-exposures to cadmium, cobalt and lead as more dangerous than hitherto expected," Carcinogenesis, vol. 24, no. 1, pp. 63-73, 2003.

[25] J. Palus, K. Rydzynski, E. Dziubaltowska, K. Wyszynska, A. T. Natarajan, and R. Nilsson, "Genotoxic effects of occupational exposure to lead and cadmium," Mutation Research, vol. 540, no. 1, pp. 19-28, 2003.

[26] J. Ponti, B. Munaro, M. Fischbach, S. Hoffmann, and E. Sabbioni, "An optimised data analysis for the Balb/c 3T3 cell transformation assay and its application to metal compounds," International Journal of Immunopathology and Pharmacology, vol. 20, no. 4, pp. 673-684, 2007.

[27] E. Rojas, P. Mussali, E. Tovar, and M. Valverde, "DNA-AP sites generation by Etoposide in whole blood cells," BMC Cancer, vol. 9, article 398, 2009.

[28] V. M. Lee, P. A. Quinn, S. C. Jennings, and L. L. Ng, "NADPH oxidase activity in preeclampsia with immortalized lymphoblasts used as models," Hypertension, vol. 41, no. 4, pp. 925-931, 2003.

[29] N. Bouaïcha and I. Maatouk, "Microcystin-LR and nodularin induce intracellular glutathione alteration, reactive oxygen species production and lipid peroxidation in primary cultured rat hepatocytes," Toxicology Letters, vol. 148, no. 1-2, pp. 5363, 2004.

[30] L. Vega, M. Valverde, G. Elizondo, J. F. Leyva, and E. Rojas, "Diethylthiophosphate and diethyldithiophosphate induce genotoxicity in hepatic cell lines when activated by further biotransformation via Cytochrome P450," Mutation Research, vol. 679, no. 1-2, pp. 39-43, 2009.

[31] H. Aebi, "Catalase in vitro," Methods in Enzymology, vol. 105, pp. 121-126, 1984.

[32] Y. Sun, L. W. Oberley, and Y. Li, "A simple method for clinical assay of superoxide dismutase," Clinical Chemistry, vol. 34, no. 3, pp. 497-500, 1988.

[33] O. Erel, "A novel automated direct measurement method for total antioxidant capacity using a new generation, more stable ABTS radical cation," Clinical Biochemistry, vol. 37, no. 4, pp. 277-285, 2004.

[34] N. Keshava, "Tumorigenicity of morphologically distinct transformed foci induced by 3-methylcholanthrene in BALB/ c-3T3 cells," Mutation Research, vol. 447, no. 2, pp. 281-286, 2000.
[35] K. Hayashi, K. Sasaki, S. Asada et al., "Technical modification of the balb/c 3T3 cell transformation assay: the use of serumreduced medium to optimise the practicability of the protocol," ATLA Alternatives to Laboratory Animals, vol. 36, no. 6, pp. 653-665, 2008.

[36] O. I. Aruoma, B. Halliwell, B. M. Hoey, and J. Butler, "The antioxidant action of $\mathrm{N}$-acetylcysteine: its reaction with hydrogen peroxide, hydroxyl radical, superoxide, and hypochlorous acid," Free Radical Biology and Medicine, vol. 6, no. 6, pp. 593-597, 1989.

[37] M. G. Mascolo, S. Perdichizzi, F. Rotondo et al., "BALB/c 3T3 cell transformation assay for the prediction of carcinogenic potential of chemicals and environmental mixtures," Toxicology in Vitro, vol. 24, no. 4, pp. 1292-1300, 2010.

[38] M. Z. Fang, D. Y. Kim, H. W. Lee, and M. H. Cho, "Improvement of in vitro two-stage transformation assay and determination of the promotional effect of cadmium," Toxicology in Vitro, vol. 15, no. 3, pp. 225-231, 2001.

[39] M. Z. Fang, W. C. Mar, and M. H. Cho, "Cadmium-induced alterations of connexin expression in the promotion stage of in vitro two-stage transformation," Toxicology, vol. 161, no. 1-2, pp. 117-127, 2001.

[40] M. D. Spruill, B. Song, W. Z. Whong, and T. Ong, "Protooncogene amplification and overexpression in cadmium-induced cell transformation," Journal of Toxicology and Environmental Health-Part A, vol. 65, no. 24, pp. 2131-2144, 2002.

[41] L. Ao, J. Y. Liu, L. H. Gao et al., "Differential expression of genes associated with cell proliferation and apoptosis induced by okadaic acid during the transformation process of BALB/c 3T3 cells," Toxicology in Vitro, vol. 22, no. 1, pp. 116-127, 2008.

[42] L. Ao, J. Y. Liu, W. B. Liu et al., "Comparison of gene expression profiles in BALB/c 3T3 transformed foci exposed to tumor promoting agents," Toxicology in Vitro, vol. 24, no. 2, pp. $430-438,2010$.

[43] M. Asmuss, L. H. F. Mullenders, A. Eker, and A. Hartwig, "Differential effects of toxic metal compounds on the activities of Fpg and XPA, two zinc finger proteins involved in DNA repair," Carcinogenesis, vol. 21, no. 11, pp. 2097-2104, 2000.

[44] A. Hartwig, M. Asmuss, I. Ehleben et al., "Interference by toxic metal ions with DNA repair processes and cell cycle control: molecular mechanisms," Environmental Health Perspectives, vol. 110, no. 5, pp. 797-799, 2002.

[45] A. Hartwig and T. Schwerdtle, "Interactions by carcinogenic metal compounds with DNA repair processes: toxicological implications," Toxicology Letters, vol. 127, no. 1-3, pp. 47-54, 2002.

[46] D. R. McNeill, A. Narayana, H. K. Wong, and D. M. Wilson, "Inhibition of Ape1 nuclease activity by lead, iron, and cadmium," Environmental Health Perspectives, vol. 112, no. 7, pp. 799-804, 2004.

[47] K. Salnikow, M. Gao, V. Voitkun, X. Huang, and M. Costa, "Altered oxidative stress responses in nickel-resistant mammalian cells," Cancer Research, vol. 54, no. 24, pp. 6407-6412, 1994.

[48] C. P. Rajneesh, A. Manimaran, K. R. Sasikala, and P. Adaikappan, "Lipid peroxidation and antioxidant status in patients with breast cancer," Singapore Medical Journal, vol. 49, no. 8, pp. 640-643, 2008.

[49] G. Pani, T. Galeotti, and P. Chiarugi, "Metastasis: cancer cell's escape from oxidative stress," Cancer and Metastasis Reviews, vol. 29, no. 2, pp. 351-378, 2010. 


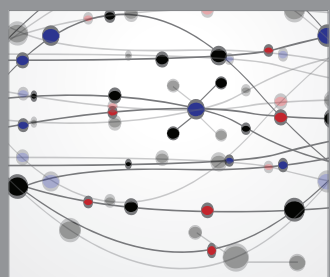

The Scientific World Journal
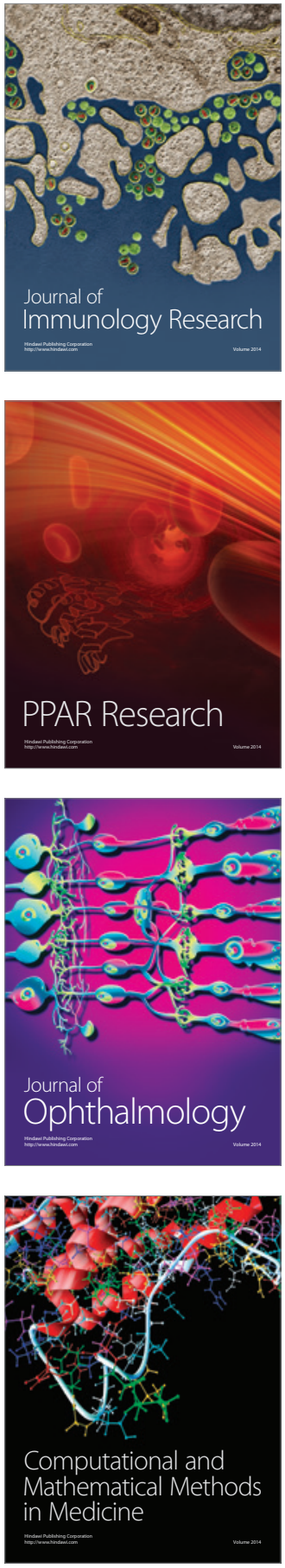

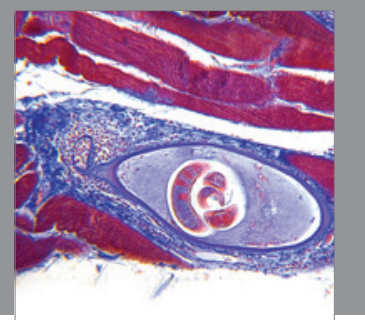

Gastroenterology

Research and Practice
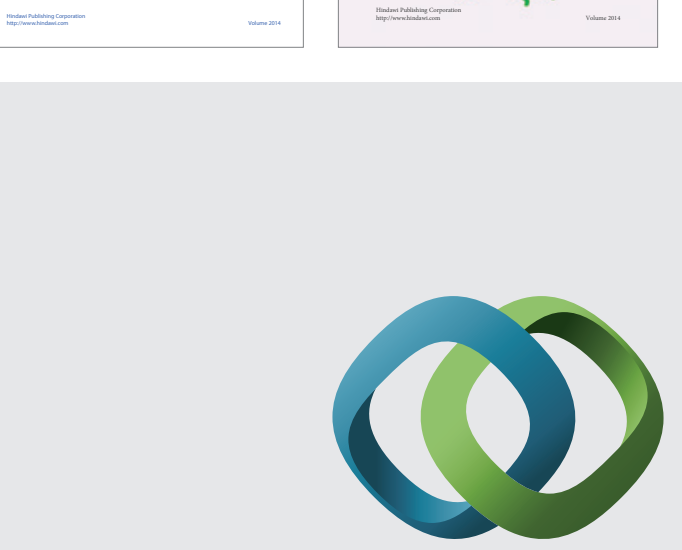

\section{Hindawi}

Submit your manuscripts at

http://www.hindawi.com
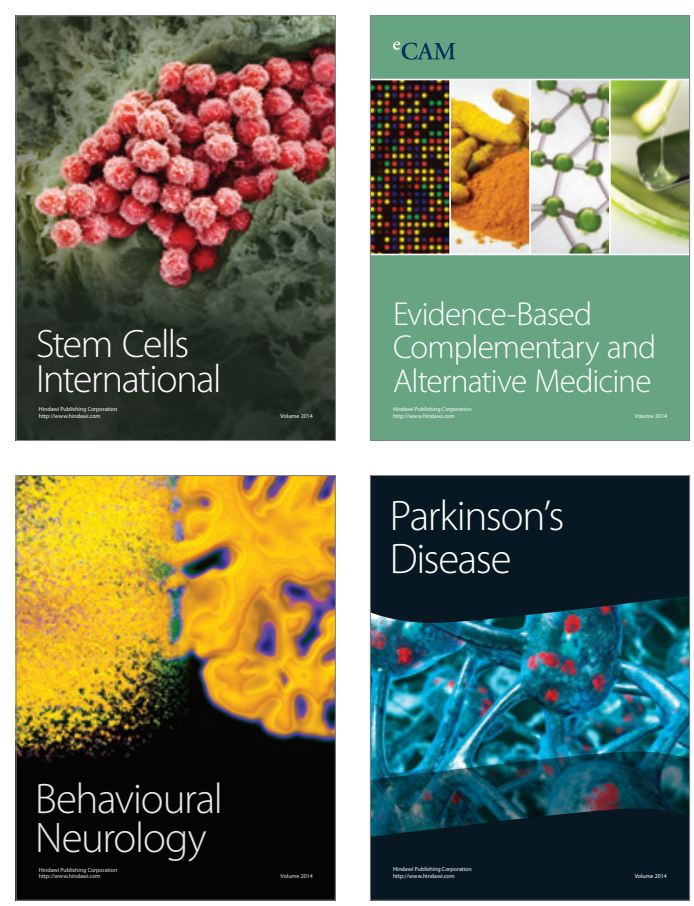

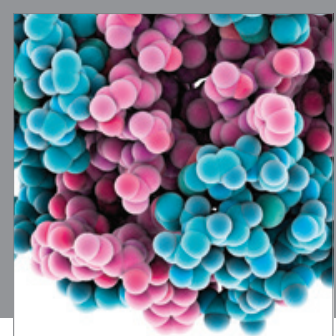

Journal of
Diabetes Research

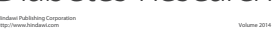

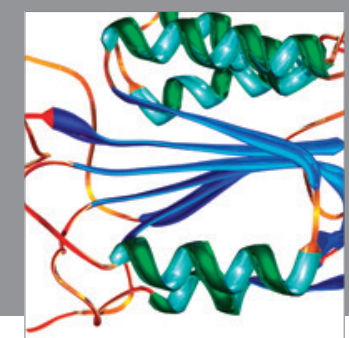

Disease Markers
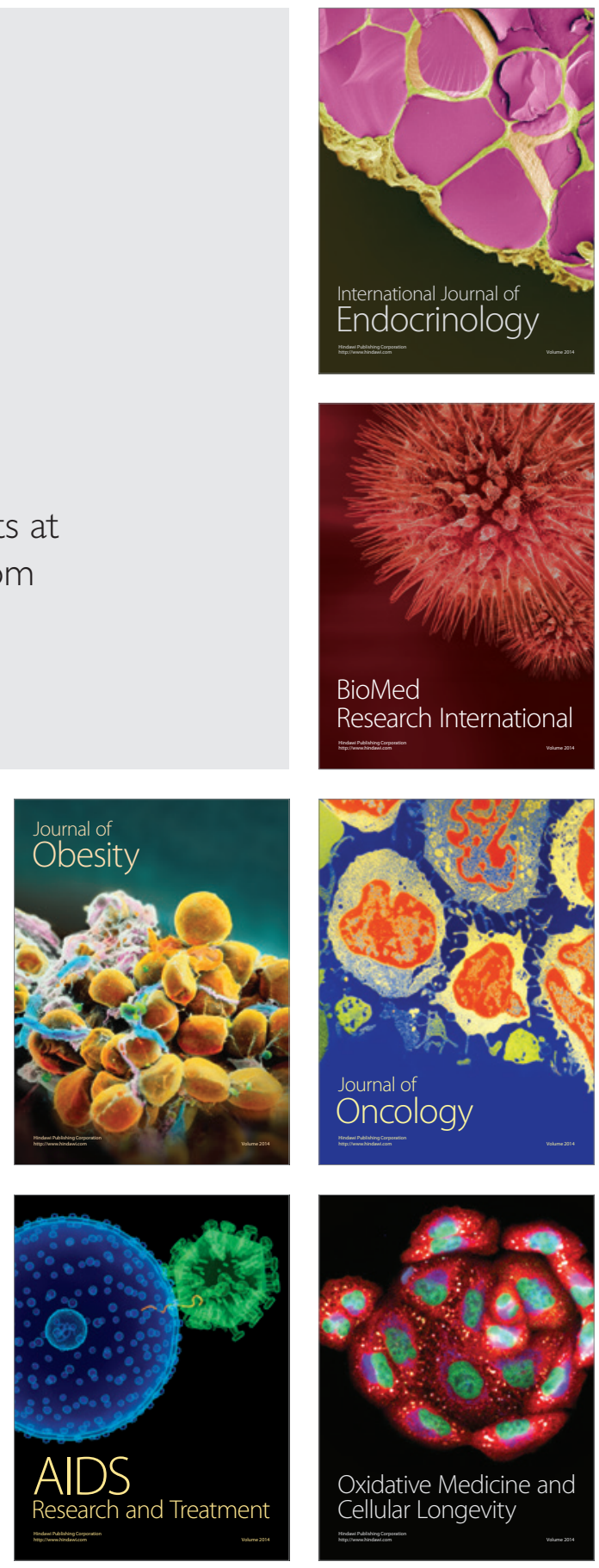